\title{
Effect of Acetolactate Synthase Inhibitor Herbicides on Upland Rice (Oryza Sativa Linn.) Cultivars
}

\author{
Fabiano André Petter ${ }^{1}$, Alan Mario Zuffo ${ }^{2} \&$ Leandro Pereira Pacheco ${ }^{3}$ \\ ${ }^{1}$ Department of Agronomy-Plant Science of University Federal of Mato Grosso, Sinop, MT, Brazil \\ ${ }^{2}$ Pos-Graduate Program in Agronomy-Plant Science of University Federal of Lavras, Lavras, MG, Brazil \\ ${ }^{3}$ Department of Agricultural Engineering of University Federal of Mato Grosso, Rondonópolis, MT, Brazil \\ Correspondence: Fabiano André Petter, Department of Agronomy-Plant Science of University Federal of Mato \\ Grosso, Sinop, MT 78557-267, Brazil. E-mail: petter@ufmt.br
}

Received: June 1, 2013 Accepted: August 1, 2013 Online Published: September 15, 2013

doi:10.5539/jas.v5n10p99 URL: http://dx.doi.org/10.5539/jas.v5n10p99

\begin{abstract}
This study aimed to evaluate the selectivity of the acetolactate synthase (ALS) inhibitor recommended herbicides for upland rice cultivars on different developmental stages. The experiment was conducted in the field, in Nova Xavantina-MT, Mato Grosso, Brazil, from season 2009/2010. The experimental design was the one of randomized blocks in factorial scheme, composed by the herbicide treatments penoxsulam $\left(36 \mathrm{~g} \mathrm{ha}^{-1}\right)$; bispyribac-sodium $(50 \mathrm{~g}$ $\left.\mathrm{ha}^{-1}\right)$; pyrazosulfuron-ethyl $\left(20 \mathrm{~g} \mathrm{ha}^{-1}\right)$ and weeded control. Herbicides were applied at three times: 15,30 and 45 days after emergence (DAE) with four replications in two upland rice cultivars: BRS Pepita and BRS Monarca. At 7, 14 and 28 days after application (DAA) the following assessments were performed: phytotoxicity to the crop, plant height, dry weight, number of panicles $\mathrm{m}^{-2}$, grains per panicle ${ }^{-1}$ and productivity. The highest levels of phytotoxicity were observed in plants treated with bispyribac-sodium applied at 15 and 30 DAE. The rice plants were able to recover as for height influenced by herbicides from 14 DAA. The dry weight of plants was not affected by herbicide application. Since they have not reduced the grain productivity, the herbicides tested, when applied at 30 DAE, have showed their potential to be used only in BRS Monarca cultivar.
\end{abstract}

Keywords: bispyribac-sodium, penoxsulam, phytotoxicity, pyrazosulfuron-ethyl, yield

\section{Introduction}

The Brazilian rice production is spread across the country with two main types of basic production systems, upland rice and irrigated one. In the Cerrado region there is predominantly upland rice, known to have a lower production. However, its usage has been growing as for crop rotation with soybeans, due to lower production cost, demand, attractive price (Pacheco et al., 2011), maintenance of soil fertility (Costa, Bayer, Albuquerque, \& Fontoura, 2004) and disruption of biological cycles of pests and diseases (Gasparim, Ricieri, Silva, Dallacort, \& Gnoatto, 2005).

The culture of upland rice, undemanding in inputs and with good tolerance to acid soils, had played a significant role as an opening cultivar to new areas during the agricultural occupation of the Cerrado region, started in the 60s (Pinheiro, 2006). In the Cerrado region, the rice farmers are returning to old areas and gradually generating the new status of rice as main crop (Beling, 2007). despite its strong sensitivity to climatic factors.

The development of rice cultivars with higher yield potential, combined with high fertility in soils earlier cultivated with soybean has provided high yields of upland rice and profitability for the farmer. However, the inclusion of this cultivar in general in the area of soybean seeding has presented some problems, such as the difficulty for weed control, since most of the areas cultivated with soybeans are highly infested by many species (Pacheco et al., 2009), moreover, the upland rice presents few herbicide options, what increases the risk of such activity.

According to Cobucci and Portela (2001), the lack of products and technology for weed control in upland rice cultivars, coupled with the low capacity of the rice to compete with these weeds, is one of the major obstacles to the introduction of this cultivar to agricultural systems. Considering chemical control of weeds has been an essential tactic to large-scale cultivation (Rajguru, Burgos, Shivrain, \& Stewart, 2005). Studies to evaluate options of herbicides with the potential to be used in post-emergence of rice cultivar can contribute to the integrated management (Andres, Freitas, Concenço, Melo, \& Ferreira, 2007). 
Among the herbicides used in integrated weed management in rice, we highlight the ALS enzyme inhibitors (acetolactate synthase), key to the processes of biosynthesis of amino acid branched chain (valine, leucine and isoleucine) (Petter, Zuffo, \& Pacheco, 2011). Herbicides with this way of action are highly used in systems of irrigated rice cultivation and little used in upland rice ones. According to Leite et al. (1998) and Vidal (2002) these products have presented a broad spectrum of action, low toxicity to humans and animals and high capacity of translocation in plants.

As for the rice grown in irrigated system, there are several studies evaluating the efficiency in the use of herbicides (Concenço et al., 2006; Machado, Barros, Zimmer, \& Amaral, 2006; Sanchotene, Dornelles, Perini, Gonçalves, \& Estevo, 2009). However, upland rice, since it is considered, wrongly, as a marginal crop in the Cerrado and of low cost, has not attracted interest from private companies to afford studies to provide new herbicide options for this crop system.

Since studies on the effect of ALS inhibitors in controlling the weeds in upland rice cultivation are scanty, the present study aims to evaluate the effectiveness of ALS inhibitor herbicides on irrigated upland rice cultivars on different developmental stages

\section{Materials and Methods}

The experiment was conducted in the field, in Nova Xavantina, Mato Grosso, Brazil (14 41' S; 52 $20^{\prime}$ W; 310 m.a.s.1.) in the period from season 2009/2010, on soil classified as Oxisol (Empresa Brasileira de Pesquisa Agropecuária [EMBRAPA], 2006). The textural analysis of soil, at 0-0.20 m layer was $400 \mathrm{~g} \mathrm{~kg}^{-1} \mathrm{clay}, 100 \mathrm{~g} \mathrm{~kg}^{-1}$ silt and $500 \mathrm{~g} \mathrm{~kg}^{-1}$ sand. The chemical compositions of soil are given in Table 1 .

Table 1. Chemical composition of soil $(0-0.20 \mathrm{~m})$ of the experimental area before the experiment installation, the 2009-2010 harvest in Nova Xavantina, Mato Grosso, Brazil

\begin{tabular}{|c|c|c|c|c|c|c|c|}
\hline \multirow{2}{*}{$\begin{array}{l}\mathrm{pH} \\
\mathrm{CaCl}_{2}\end{array}$} & P (Mehlich) & $\mathrm{K}$ & $\mathrm{Ca}$ & $\mathrm{Mg}$ & $\mathrm{Al}$ & $\mathrm{H}+\mathrm{Al}$ & \multirow{2}{*}{$\begin{array}{l}\text { O.M. }^{1} \\
--\mathrm{g} \mathrm{dm}^{-3}-\end{array}$} \\
\hline & \multicolumn{2}{|c|}{----- $\mathrm{mg} \mathrm{dm}^{-3}$----- } & \multicolumn{4}{|c|}{----- $\mathrm{cmol}_{\mathrm{c}} \mathrm{dm}^{-3}$----- } & \\
\hline 5.2 & 11,6 & 70,0 & 2,7 & 0,8 & 0,1 & 5,2 & 29,0 \\
\hline $\mathrm{V}^{2}$ & $\mathrm{CEC}^{3}$ & $\mathrm{Fe}$ & $\mathrm{B}$ & $\mathrm{Mn}$ & $\mathrm{Zn}$ & $\mathrm{Cu}$ & $\mathrm{S}$ \\
\hline$\%$ & $\mathrm{cmol}_{\mathrm{c}} \mathrm{dm}^{-3}$ & \multicolumn{6}{|c|}{ 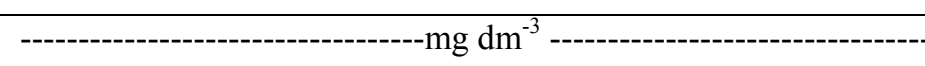 } \\
\hline 41 & 8,8 & 44 & 0,2 & 24 & 1,5 & 2,4 & 6,4 \\
\hline
\end{tabular}

${ }^{1}$ O.M.: organic matter; ${ }^{2} \mathrm{~V} \%$ : base saturation; ${ }^{3} \mathrm{CEC}$ : cation exchange capacity.

The climate is Aw according to Köppen classification, with two well defined seasons, with a drought one that lasts from May to September and a rainy one that goes from October to April. The weather conditions during the experiment are shown in Figure 1.

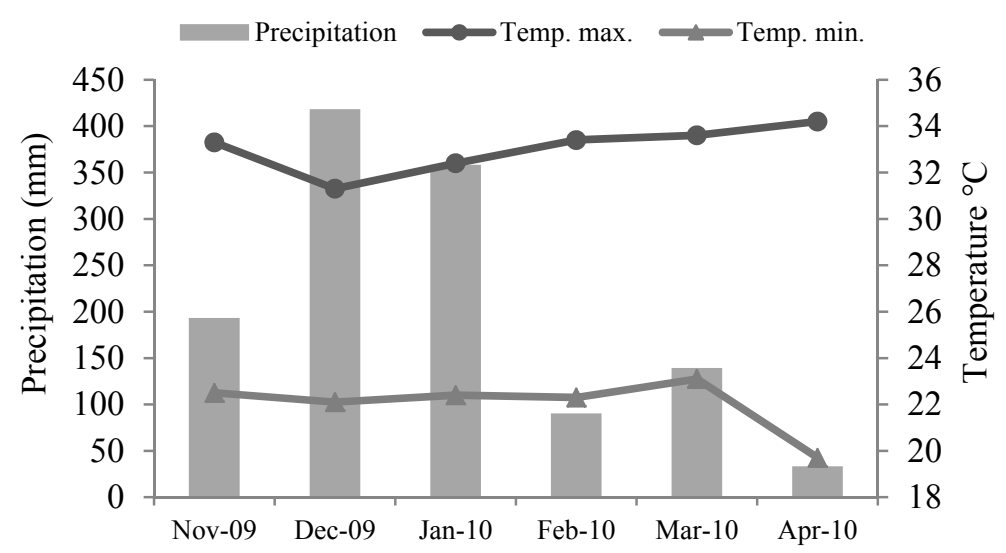

Figure 1. Precipitation $(\mathrm{mm})$ and temperature $\left({ }^{\circ} \mathrm{C}\right)$ occurred monthly during the experiment. (Source: Experimental Station Inmet in Nova Xavantina, Mato Grosso, Brazil) 
The rice rainfed was grown in conventional tillage, being performed an operation of tillage with harrowing two days before sowing. The area had a history of soybean cultivation for five consecutive years. The sowing of rice cultivars (BRS Pepita and BRS Monarca) was held on December 22, 2009, with row spacing of $0.20 \mathrm{~m}$ and with $80-90$ seeds distributed per meter of furrow. The basic NPK fertilization consisted of $150 \mathrm{~kg} \mathrm{ha}^{-1}$ of the formula (05-25-15) distributed along the furrows. Fertilization of the yield covering was performed by applying $160 \mathrm{~kg} \mathrm{ha}^{-1}$ of the formula 20-00-00, divided at 25 and 35 days after emergence (DAE).

The experiment was conducted in a factorial design, using a randomized block design with four replications. The treatments consisted of herbicides penoxsulam $\left(36 \mathrm{~g} \mathrm{ha}^{-1}\right)$, pyrazosulfuron-ethyl $\left(20 \mathrm{~g} \mathrm{ha}^{-1}\right)$ and bispyribac-sodium $\left(50 \mathrm{~g} \mathrm{ha}^{-1}\right)$, applied three times: 15,30 and 45 days after emergence (DAE) and weed control in two cultivars of upland rice: BRS Pepita and BRS Monarca. Each plot consisted of $4 \mathrm{~m}$ wide (twenty lines of cultivar) and $4 \mathrm{~m}$ long. As for the usable area, $0.5 \mathrm{~m}$ on each side of the plot and $0.5 \mathrm{~m}$ in the extremities were dropped out, accounting for $9 \mathrm{~m}^{2}$ of usable area.

The herbicide application was done by using a backpack sprayer pressurized with $\mathrm{CO}_{2}$, the bar coupled with four spray nozzles bar XR 110.02, with constant pressure of $2 \mathrm{kgf} \mathrm{cm}^{-2}$, applying spray volume equivalent to $125 \mathrm{~L} \mathrm{ha}^{-1}$.

During the cultivar development phytosanitary treatment was perfomed, with an application of the insecticide methamidophos $\left(420 \mathrm{~g} \mathrm{ha}^{-1}\right)$ and an application of the fungicide tricyclazole $\left(225 \mathrm{~g} \mathrm{ha}^{-1}\right)$ when the cultivar was $5 \%$ of the issued panicles.

At 7, 14 and 28 days after application (DAA) of herbicides the following observation were recorded: a) the phytotoxicity to the cultivar, through visual score ranging from 0 to $100 \%$ compared to control, in which zero represents the absence of injuries, and $100 \%$ stands for the death of plants; b) plant height, measuring 20 random plants per plot, through the use of graduated tape; c) dry weight of plants, collecting 10 plants per plot and then drying them in forced circulation greenhouse at $70{ }^{\circ} \mathrm{C}$ for 72 hours. In pre-harvest, the number of panicles per $\mathrm{m}^{-2}$ and number of grains per panicle ${ }^{-1}$ were evaluated and, at harvest, the productivity was measured, with standardization to $13 \%$ moisture content in grains.

The data were subjected to analysis of variance, being the averages of the significant variables grouped by Tukey test at 5\% significance level, using the statistical program Sisvar. For the analysis of phytotoxicity data, they were transformed into Arc-sin $(x+1)^{0.5}$, however, the values presented are the original averages.

\section{Results and Discussion}

Regardless of cultivar, phytotoxic effect was observed only as for bispyribac-sodium application at 15 and 30 days after emergence (DAE) (Table 2). The visual damage in BRS Pepita, when the herbicide was applied at 15 DAE, was more intense at 14 and 28 days after application (DAA), from $4 \%$ at 7 DAA to $16 \%$ at 14 and 28 DAA. In the application at $30 \mathrm{DAE}$, the phytointoxication symptoms were detected during the evaluation period. In BRS Monarca, regardless of the evaluation period, the applications at 15 and 30 DAE provided visual damage with $20 \%$ injury, characterized by a slight chlorosis on the leaves. These results corroborate those obtained by Petter et al. (2011), who have found visual phytotoxicity symptoms up to 37\% in upland rice cultivar cv. Cambará.

The phytotoxic effect characterized by chlorosis is typical of herbicides with physiological action, there is, products with good translocation and directly interference in the metabolism of plants, which is the case of bispyribac-sodium (Rodrigues \& Almeida, 2005). The plant tolerance to ALS inhibitor herbicides is related to an alteration of the gene responsible for encoding this enzyme (Tranel \& Wright, 2002). An increased ability of the crop to metabolize the herbicide, coupled with the morphological differentiation of plants, such as cuticle thickness (Vidal, 2002) and high leaf area index (Stone \& Pereira, 1994) at 45 DAE, may explain the absence of toxic effect on plants when the herbicide bispyribac-sodium was applied in this period. Despite the physical and chemical constitution of the cuticle being the same at different stages of development, cuticles of younger leaves are more permeable (Silva, Freitas, Ferreira, \& Fontes, 2009) because they have lower lipid composition, besides the occurrence of genetic alterations in each upland rice cultivar (Corbett \& Tardiff, 2006).

These results demonstrate that the use of bispyribac-sodium until the 30 DAE may compromise the cultivar development, particularly in conditions of water deficit, since the ability of metabolizing the product is impaired due to the reduction of the plant metabolism. According to Taiz and Zeiger (2009), the metabolism of plants is reduced in water deficit conditions.

Only BRS Monarca had the plant height significantly influenced $(p<0.05)$ by herbicide application (Table 3$)$. This effect was observed in the applications made at 15 and 30 DAE and only during the first assessment at 7 DAA. Just an early application of the bispyribac-sodium herbicide at 15 DAE resulted in reduced plant height, and only in the evaluation at 7 DAA, whereas as for the subsequent evaluations (14 and 28 DAA), no effect was detected over this 
herbicide. In the application at $30 \mathrm{DAE}$, for all herbicides a reduction in plant height was observed at $7 \mathrm{DAA}$, with the largest decreases observed for pyrazosulfuron-ethyl and bispyribac-sodium, which have decreased by $20 \%$ plant height if compared to the control without herbicide. However, as for the assessments at 14 and 28 DAA a significant difference for this variable was no longer detected, showing good resilience of these cultivars to the deleterious effect of these herbicides. Similar behavior was observed by Petter et al. (2012) in plants of upland rice cv. BRS Sertaneja, in which plants recovered from the deleterious effects in their height due to the application of herbicides bispyribac-sodium, penoxsulan and pyrazosulfuron-ethyl.

Table 2. Phytotoxicity in rice cultivars submitted to the application of herbicides at different times after crop emergence, the 2009-2010 harvest in Nova Xavantina, Mato Grosso, Brazil

\begin{tabular}{|c|c|c|c|c|c|c|c|}
\hline \multirow{3}{*}{ Herbicides (rate $\mathrm{g} \mathrm{ha}^{-1}$ ) } & \multirow{3}{*}{ Application time* } & \multicolumn{6}{|c|}{ Injury $(\%)$} \\
\hline & & \multicolumn{2}{|c|}{$7 \mathrm{DAA}^{* *}$} & \multicolumn{2}{|c|}{$14 \mathrm{DAA}^{* *}$} & \multicolumn{2}{|c|}{$28 \mathrm{DAA}^{* *}$} \\
\hline & & BRS Pepita & BRS Monarca & BRS Pepita & BRS Monarca & BRS Pepita & BRS Monarca \\
\hline penoxsulam (36) & \multirow{4}{*}{$15 \mathrm{DAE}$} & $0,0 \mathrm{a}$ & $0,0 \mathrm{a}$ & $0,0 \mathrm{a}$ & $0,0 \mathrm{a}$ & $0,0 \mathrm{a}$ & $0,0 \mathrm{a}$ \\
\hline pyrazosulfuron-ethyl (20) & & $0,0 \mathrm{a}$ & $0,0 \mathrm{a}$ & $0,0 \mathrm{a}$ & $0,0 \mathrm{a}$ & $0,0 \mathrm{a}$ & $0,0 \mathrm{a}$ \\
\hline bispyribac-sodium (50) & & $3,7 \mathrm{~b}$ & $20 \mathrm{~b}$ & $16 \mathrm{~b}$ & $20 \mathrm{~b}$ & $16 \mathrm{~b}$ & $20 \mathrm{~b}$ \\
\hline control & & $0,0 \mathrm{a}$ & $0,0 \mathrm{a}$ & $0,0 \mathrm{a}$ & $0,0 \mathrm{a}$ & $0,0 \mathrm{a}$ & $0,0 \mathrm{a}$ \\
\hline Average & & $1,0 \mathrm{~A}$ & $5,0 \mathrm{~B}$ & $2,0 \mathrm{~A}$ & $5,0 \mathrm{~B}$ & $2,0 \mathrm{~A}$ & $5,0 \mathrm{~B}$ \\
\hline penoxsulam (36) & \multirow{4}{*}{$30 \mathrm{DAE}$} & $0,0 \mathrm{a}$ & $0,0 \mathrm{a}$ & $0,0 \mathrm{a}$ & $0,0 \mathrm{a}$ & $0,0 \mathrm{a}$ & $0,0 \mathrm{a}$ \\
\hline pyrazosulfuron-ethyl (20) & & $0,0 \mathrm{a}$ & $0,0 \mathrm{a}$ & $0,0 \mathrm{a}$ & $0,0 \mathrm{a}$ & $0,0 \mathrm{a}$ & $0,0 \mathrm{a}$ \\
\hline bispyribac-sodium (50) & & $20 \mathrm{~b}$ & $20 \mathrm{~b}$ & $20 \mathrm{~b}$ & $20 \mathrm{~b}$ & $20 \mathrm{~b}$ & $20 \mathrm{~b}$ \\
\hline control & & $0,0 \mathrm{a}$ & $0,0 \mathrm{a}$ & $0,0 \mathrm{a}$ & $0,0 \mathrm{a}$ & $0,0 \mathrm{a}$ & $0,0 \mathrm{a}$ \\
\hline Average & & $5,0 \mathrm{~B}$ & $5,0 \mathrm{~B}$ & $5,0 \mathrm{~B}$ & $5,0 \mathrm{~B}$ & $5,0 \mathrm{~B}$ & $5,0 \mathrm{~B}$ \\
\hline penoxsulam (36) & \multirow{4}{*}{$45 \mathrm{DAE}$} & $0,0^{\text {ns }}$ & $0,0^{\mathrm{ns}}$ & $0,0^{\text {ns }}$ & $0,0^{\text {ns }}$ & $0,0^{\text {ns }}$ & $0,0^{\text {ns }}$ \\
\hline pyrazosulfuron-ethyl (20) & & 0,0 & 0,0 & 0,0 & 0,0 & 0,0 & 0,0 \\
\hline bispyribac-sodium (50) & & 0,0 & 0,0 & 0,0 & 0,0 & 0,0 & 0,0 \\
\hline control & & 0,0 & 0,0 & 0,0 & 0,0 & 0,0 & 0,0 \\
\hline Average & & $0,0 \mathrm{~A}$ & $0,0 \mathrm{~A}$ & $0,0 \mathrm{~A}$ & $0,0 \mathrm{~A}$ & $0,0 \mathrm{~A}$ & $0,0 \mathrm{~A}$ \\
\hline
\end{tabular}

Means followed by same lowercase letters in the column, and capital letters in the column of averages, not statistically different by Tukey test (5\%). * Days after crop emergence. ${ }^{* *}$ Days after herbicide application. ${ }^{\text {ns }}-$ not significant.

Table 3. Height of rice plants after herbicide application at different times after crop emergence, the 2009-2010 harvest in Nova Xavantina, Mato Grosso, Brazil

\begin{tabular}{|c|c|c|c|c|c|c|c|}
\hline \multirow{3}{*}{ Herbicides (rate $\mathrm{g} \mathrm{ha}^{-1}$ ) } & \multirow{3}{*}{ Application time* } & \multicolumn{6}{|c|}{ Height of plants $(\mathrm{cm})$} \\
\hline & & \multicolumn{2}{|c|}{$7 \mathrm{DAA}^{* *}$} & \multicolumn{2}{|c|}{$14 \mathrm{DAA}^{* *}$} & \multicolumn{2}{|c|}{$28 \mathrm{DAA}^{* *}$} \\
\hline & & BRS Pepita & BRS Monarca & BRS Pepita & BRS Monarca & BRS Pepita & BRS Monarca \\
\hline penoxsulam (36) & \multirow{4}{*}{$15 \mathrm{DAE}$} & $37^{\text {ns }}$ & $31 \mathrm{AB}$ & $53^{\text {ns }}$ & $47^{\text {ns }}$ & $76^{\text {ns }}$ & $66^{\mathrm{ns}}$ \\
\hline pyrazosulfuron-ethyl (20) & & 35 & $35 \mathrm{~A}$ & 53 & 49 & 75 & 69 \\
\hline bispyribac-sodium (50) & & 31 & $28 \mathrm{~B}$ & 52 & 42 & 74 & 58 \\
\hline control & & 37 & $37 \mathrm{~A}$ & 58 & 50 & 76 & 73 \\
\hline penoxsulam (36) & \multirow{4}{*}{$30 \mathrm{DAE}$} & $70^{\text {ns }}$ & $60 \mathrm{~B}$ & $75^{\mathrm{ns}}$ & $64^{\mathrm{ns}}$ & $83^{\text {ns }}$ & $75^{\mathrm{ns}}$ \\
\hline pyrazosulfuron-ethyl (20) & & 69 & $58 \mathrm{~B}$ & 74 & 69 & 83 & 73 \\
\hline bispyribac-sodium (50) & & 69 & $58 \mathrm{~B}$ & 71 & 65 & 76 & 71 \\
\hline control & & 73 & $72 \mathrm{~A}$ & 78 & 75 & 85 & 77 \\
\hline penoxsulam (36) & \multirow{4}{*}{$45 \mathrm{DAE}$} & $80^{\text {ns }}$ & $70^{\mathrm{ns}}$ & $83^{\text {ns }}$ & $71^{\mathrm{ns}}$ & $96^{\mathrm{ns}}$ & $90^{\mathrm{ns}}$ \\
\hline pyrazosulfuron-ethyl (20) & & 82 & 71 & 85 & 71 & 95 & 90 \\
\hline bispyribac-sodium (50) & & 78 & 77 & 81 & 77 & 87 & 91 \\
\hline control & & 83 & 78 & 85 & 85 & 104 & 96 \\
\hline
\end{tabular}

Means followed by the same letters in the same columns do not differ by the Tukey test at $5 \%$ probability. * Days after crop emergence. ${ }^{* *}$ Days after herbicide application. ${ }^{\text {ns }}-$ not significant. 
Similarly, Sanchotene et al. (2009) have found that rice varieties showed no reduction in plant height from 30 days after penoxsulam and bispyribac-sodium herbicide application. It is noteworthy that the ability of plants to metabolize compounds is directly related to their metabolic activity, being more intense near the flowering stage. The lack of effect as for late application of herbicides (45 DAE) on plant height was expected, because early maturity cultivars of upland rice (105-115 days), usually at 45 DAE have already ceased height growth of plants. According to Fornasieri Filho and Fornasieri (2006) rice cultivars with 155 DAE cycle present vegetative phase around 50 days.

There was no significant effect $(\mathrm{p}<0.05)$ of herbicide application on dry matter accumulation, regardless of time of application and evaluation (Table 4). Similar results were obtained by Petter et al. (2011), who have found no reduction in dry matter accumulation by applying bispyribac-sodium, penoxsulan and pyrazosulfuron-ethyl in upland rice, however, it differs from those observed by Concenço et al. (2007), in which various dosages of bispyribac-sodium reduced height and dry weight of plants in two irrigated rice cultivars. This way, a different behavior of upland and irrigated rice cultivars is evident, when subjected to the application of these herbicides.

Table 4. Dry weight of rice plants after herbicide application at different times after crop emergence, the 2009-2010 harvest in Nova Xavantina, Mato Grosso, Brazil

\begin{tabular}{|c|c|c|c|c|c|c|c|}
\hline \multirow{3}{*}{ Herbicides (rate $\mathrm{g} \mathrm{ha}^{-1}$ ) } & \multirow{3}{*}{ Application time* } & \multicolumn{6}{|c|}{ Dry weight (g $10^{-1}$ plants) } \\
\hline & & \multicolumn{2}{|c|}{$7 \mathrm{DAA}^{* *}$} & \multicolumn{2}{|c|}{$14 \mathrm{DAA}^{* *}$} & \multicolumn{2}{|c|}{$28 \mathrm{DAA}^{* *}$} \\
\hline & & BRS Pepita & BRS Monarca & BRS Pepita & BRS Monarca & BRS Pepita & BRS Monarca \\
\hline penoxsulam (36) & \multirow{4}{*}{$15 \mathrm{DAE}$} & $1,9^{\mathrm{ns}}$ & $1,7^{\mathrm{ns}}$ & $4,5^{\mathrm{ns}}$ & $3,3^{\text {ns }}$ & $9,8^{\text {ns }}$ & $11^{\mathrm{ns}}$ \\
\hline pyrazosulfuron-ethyl (20) & & 2,2 & 1,7 & 3,9 & 3,5 & 13 & 8,5 \\
\hline bispyribac-sodium (50) & & 2,4 & 1,9 & 4,1 & 2,7 & 11 & 8,2 \\
\hline control & & 2,5 & 2,3 & 5,0 & 3,5 & 12 & 12 \\
\hline penoxsulam (36) & \multirow{4}{*}{$30 \mathrm{DAE}$} & $7,1^{\mathrm{ns}}$ & $6,6^{\mathrm{ns}}$ & $12^{\mathrm{ns}}$ & $9,8^{\mathrm{ns}}$ & $18^{\text {ns }}$ & $17^{\text {ns }}$ \\
\hline pyrazosulfuron-ethyl (20) & & 7,9 & 5,0 & 11 & 9,5 & 16 & 15 \\
\hline bispyribac-sodium (50) & & 7,2 & 6,5 & 11 & 11 & 18 & 16 \\
\hline control & & 8,3 & 6,7 & 13 & 12 & 20 & 20 \\
\hline penoxsulam (36) & \multirow{4}{*}{$45 \mathrm{DAE}$} & $14^{\text {ns }}$ & $11^{\mathrm{ns}}$ & $16^{\text {ns }}$ & $13^{\text {ns }}$ & $25^{\mathrm{ns}}$ & $22^{\text {ns }}$ \\
\hline pyrazosulfuron-ethyl (20) & & 14 & 10 & 20 & 16 & 23 & 29 \\
\hline bispyribac-sodium (50) & & 12 & 12 & 19 & 15 & 22 & 22 \\
\hline control & & 15 & 13 & 20 & 17 & 25 & 34 \\
\hline
\end{tabular}

Means followed by the same letters in the same columns do not differ by the Tukey test at $5 \%$ probability. * Days after crop emergence. ${ }^{* *}$ Days after herbicide application. ${ }^{\text {ns }}-$ not significant.

The application as early as possible, at $15 \mathrm{DAE}$, did not influence significantly the number of panicles per $\mathrm{m}^{-2}$, independently of cultivar and the herbicide used (Table 5). As for BRS Pepita, there has been a reduction in the number of panicles per $\mathrm{m}^{-2}$ with the application of pyrazosulfuron-ethyl at 30 and $45 \mathrm{DAE}$. As for BRS Monarca, a reduction in number of panicles per $\mathrm{m}^{-2}$ was observed only with the application at $45 \mathrm{DAE}$, regardless of herbicide used. These results corroborate those obtained by Petter et al. (2012), who have also found a reduction in the number of panicles per $\mathrm{m}^{-2}$ with the application of these herbicides at 45 DAE in upland rice.

The number of grains panicle ${ }^{-1}$ was significantly $(p<0.05)$ affected by herbicide application only in BRS Monarca regardless of application timing (Table 5). In the application at $15 \mathrm{DAE}$, all herbicides reduced the number of grains panicle ${ }^{-1}$, especially pyrazosulfuron-ethyl, which provided $34 \%$ reduction for this variable if compared to the control. In the application at $30 \mathrm{DAE}$, only herbicides pyrazosulfuron-ethyl and bispyribac-sodium reduced the number of grains panicle ${ }^{-1}$. In the application at $45 \mathrm{DAE}$, there has been an effect of penoxsulam and pyrazosulfuron-ethyl herbecides, which decreased by $34 \%$ and $27 \%$, respectively, the number of grains panicle $e^{-1}$. These results are similar to those obtained by Petter et al. (2011), who have found a 30\% reduction in the number of grains panicle ${ }^{-1}$ with the application of pyrazosulfuron-ethyl at 45 DAE in upland rice cv. Cambará. According 
to these authors, this effect can be attributed to the fact that at the time of application, although the number of panicles was already set, the number of grains panicle ${ }^{-1}$ was yet to be defined.

However, Petter et al. (2012) have found no effect of these herbicides in the number of grains panicle ${ }^{-1}$ for cv. BRS Sertaneja. These contrasting results are due to variations in the behavior of rice cultivars concerning the sensitivity to ALS inhibitor herbicides, which is associated with genetic variations of various materials (Geraldo, Rossiello, Araújo, \& Pimentel, 2000).

Table 5. Panicle, grains per panicle and grain yield of rice cultivars after application of herbicides at different times after crop emergence, the 2009-2010 harvest in Nova Xavantina, Mato Grosso, Brazil

\begin{tabular}{|c|c|c|c|c|c|c|c|}
\hline \multirow{3}{*}{ Herbicides $\left(\right.$ rate $\mathrm{g} \mathrm{ha}^{-1}$ ) } & \multirow{3}{*}{ Application time* } & \multirow{2}{*}{\multicolumn{2}{|c|}{$\mathrm{N}^{\circ}$ panicle $\mathrm{m}^{-2}$}} & \multirow{2}{*}{\multicolumn{2}{|c|}{$\mathrm{N}^{\circ}$ grains panicle ${ }^{-1}$}} & \multirow{2}{*}{\multicolumn{2}{|c|}{$\frac{\text { Grain yeld }}{\mathrm{kg} \mathrm{ha}^{-1}}$}} \\
\hline & & & & & & & \\
\hline & & BRS Pepita & BRS Monarca & BRS Pepita & BRS Monarca & BRS Pepita & BRS Monarca \\
\hline penoxsulam (36) & \multirow{4}{*}{$15 \mathrm{DAE}$} & $155^{\mathrm{ns}}$ & $109^{\text {ns }}$ & $85^{\mathrm{ns}}$ & $80 \mathrm{~b}$ & $1898 \mathrm{~b}$ & $771 \mathrm{~b}$ \\
\hline pyrazosulfuron-ethyl (20) & & 173 & 95 & 88 & $79 \mathrm{~b}$ & $1977 \mathrm{~b}$ & $1004 \mathrm{a}$ \\
\hline bispyribac-sodium (50) & & 170 & 99 & 102 & $86 \mathrm{~b}$ & $1997 \mathrm{~b}$ & $710 \mathrm{~b}$ \\
\hline control & & 205 & 145 & 103 & $116 \mathrm{a}$ & 2769 a & $1191 \mathrm{a}$ \\
\hline Average & & $175 \mathrm{~A}$ & $112 \mathrm{~A}$ & $95 \mathrm{~A}$ & $90 \mathrm{~A}$ & $2160 \mathrm{~A}$ & $919 \mathrm{~A}$ \\
\hline penoxsulam (36) & \multirow{4}{*}{$30 \mathrm{DAE}$} & $196 \mathrm{a}$ & $135^{\mathrm{ns}}$ & $84^{\mathrm{ns}}$ & $110 \mathrm{ab}$ & $2034 \mathrm{~b}$ & $990^{\text {ns }}$ \\
\hline pyrazosulfuron-ethyl (20) & & $134 \mathrm{~b}$ & 99 & 83 & $85 \mathrm{~b}$ & $1735 \mathrm{~b}$ & 942 \\
\hline bispyribac-sodium (50) & & $188 \mathrm{ab}$ & 109 & 96 & $88 \mathrm{~b}$ & $2061 \mathrm{~b}$ & 975 \\
\hline control & & $205 \mathrm{a}$ & 145 & 103 & $116 \mathrm{a}$ & $2769 a$ & 1191 \\
\hline Average & & $180 \mathrm{~A}$ & $122 \mathrm{~A}$ & $91 \mathrm{~A}$ & $100 \mathrm{~A}$ & 2149 A & $1024 \mathrm{~A}$ \\
\hline penoxsulam (36) & \multirow{4}{*}{$45 \mathrm{DAE}$} & $175 \mathrm{a}$ & $49 \mathrm{~b}$ & $102^{\mathrm{ns}}$ & $78 \mathrm{~b}$ & $1312 \mathrm{~b}$ & $562 \mathrm{~b}$ \\
\hline pyrazosulfuron-ethyl (20) & & $114 \mathrm{~b}$ & $81 \mathrm{~b}$ & 101 & $85 \mathrm{~b}$ & $916 \mathrm{~b}$ & $796 \mathrm{~b}$ \\
\hline bispyribac-sodium (50) & & $149 \mathrm{ab}$ & $73 \mathrm{~b}$ & 104 & $109 \mathrm{ab}$ & $543 \mathrm{c}$ & $863 \mathrm{~b}$ \\
\hline control & & $205 \mathrm{a}$ & $145 \mathrm{a}$ & 103 & $116 \mathrm{a}$ & 2769 a & $1191 \mathrm{a}$ \\
\hline Average & & $160 \mathrm{~B}$ & $78 \mathrm{~B}$ & $102 \mathrm{~A}$ & $97 \mathrm{~A}$ & $1385 \mathrm{~B}$ & $853 \mathrm{~B}$ \\
\hline
\end{tabular}

Means followed by same lowercase letters in the column, and capital letters in the column of averages, not statistically different by Tukey test $(5 \%) .{ }^{*}$ Days after crop emergence. ${ }^{* *}$ Days after herbicide application. ${ }^{\mathrm{ns}}-$ not significant.

The negative effects of these herbicides in the number of panicles and grain panicle ${ }^{-1}$ can be explained by the same mechanism of action, since they are molecules capable of inhibiting the ALS enzyme involved in the biosynthesis of amino acids, which are precursors of protein synthesis and growth of meristematic structures (reproductive) and may affect the development of panicles, number of spikelets per panicle and the number of grains per panicle. Ray (1984) and Claus (1987) have reported that the ALS inhibitors when absorbed, are translocated into meristematic regions, inhibiting cell division, causing a decrease in the growth and death of tissues.

The grain yield of BRS Pepita was significantly $(\mathrm{p}<0.05)$ affected by herbicide application regardless of application timing (Table 5). The lowest yields of BRS Pepita were verified by applying pyrazosulfuron-ethyl and bispyribac-sodium, being $45 \mathrm{DAE}$ the time for the application of herbicides which provided the greatest reduction. As for BRS Monarca, only applications at 30 DAE did not significantly affect grain yield. These results corroborate those obtained by Cobucci and Portela (2001), who have observed that the most appropriate time for the post-emergence application of herbicides in different cultivars of upland rice was at 30 DAE.

In general, it is expected that the harmful effect of herbicides to yield is a reflection of fewer grains and grains panicle ${ }^{-1}$, even if not often significant. However, it appears that as for the BRS Monarca, even with the smallest number of grains panicle ${ }^{-1}$ with the application at 30 DAE, the yield was not affected, while as for BRS Pepita, even with no effect of herbicides and application time for this variable an effect on the final yield has been 
observed. It is clearly evident that the yield of upland rice should be treated with caution for possible verification of the sensitivity of the cultivar to the ALS inhibitor herbicides. Studies have shown that variables such as number of panicles and grain yield may not correlate with the production (Stone \& Moreira, 2000; Oliveira, Carvalho, \& Moraes, 2002), due to the unevenness in the booth, as well as for production components such as radiation, which makes their measurement much more difficult and, consequently, provides high coefficients of variation.

Data from this study, combined with results of Petter et al. (2011) and Petter et al. (2012), clearly show the different behavior of upland rice cultivars to the ALS inhibitor herbicides and one should, therefore, perform similar works, whenever he wishes to apply them in a particular cultivar, there is, one cannot extrapolate the recommending use of these herbicides for all upland rice cultivars.

The low average productivity observed in the experiment (Table 5) is due to the occurrence of dry periods during the harvest (Figure 1), coinciding with the reproductive stage of cultivar (Feb/10). Water stress is primarily responsible for low productivity and instability of upland rice (Steinmetz, Silva, \& Santana, 2006).

\section{Conclusions}

The herbicide bispyribac-sodium causes phytotoxicity in rice cv. BRS Pepita and BRS Monarca, when applied at 15 and 45 days after crop emergence. The herbicides tested did not influence the dry matter accumulation in BRS Pepita and BRS Monarca. BRS Pepita has a sensitivity to the herbicide pyrazosulfuron-ethyl concerning the number of panicles $\mathrm{m}^{-2}$, while BRS Monarca presents a sensitivity to pyrazosulfuron-ethyl and penoxsulam as for the number of grains panicle ${ }^{-1}$. BRS Pepita is highly sensitive to herbicides, while BRS Monarca has good tolerance to these herbicides applied at 30 DAE.

\section{References}

Andres, A., Freitas, G. D., Concenço, G., Melo, P. T. B. S., \& Ferreira, F. A. (2007). Performance of rice cultivar BRS pelota and control of (Echinochloa spp.) submitted to four flooding times after reduced herbicide dose application. Planta Daninha, 25, 859-867. http://dx.doi.org/10.1590/S0100-83582007000400023

Beling, R. R. (2007). Anuário brasileiro do arroz. Santa Cruz do Sul: Editora Gazeta.

Claus, J. S. (1987). Chlorimuron-ethyl (Classic): A new broadleaf post emergence herbicide in soybean. Weed Technology, 1, 114-115. Retrieved from http://www.cabdirect.org/abstracts/19870799868.html;jsessionid=45E7F7ACA7F67C70A7ADED6C63EB 7B33

Cobucci, T., \& Portela, C. (2001). Seletividade de herbicidas aplicados em diferentes estádios de desenvolvimento na cultura do arroz de terras altas. Planta Daninha, 19, 359-366. http://dx.doi.org/10.1590/S0100-83582001000300008

Concenço, G., Andres, A., Lopes, N. F., Moraes, D. M., Resende, R. G., \& Fontoura, T. P. (2006). Efeito de herbicidas aplicados em pré-emergência e momentos de início da irrigação no crescimento de plantas de arroz. Planta Daninha, 24, 295-301. http://dx.doi.org/10.1590/S0100-83582006000200012

Concenço, G., Andres, A., Lopes, N. F., Rieffel Filho, J. A., Santos, M. Q., Garcia, C. A. N., \& Ferreira, F. A. (2007). Sensibilidade de plantas de arroz ao herbicida byspiribac-sodium em função de doses e locais de aplicação. Planta daninha, 25, 629-637. http://dx.doi.org/10.1590/S0100-83582007000300024

Corbett, C. L., \& Tardif, F. J. (2006). Detection of resistance to acetolactate synthase inhibitors in weeds with emphasis on DNA-based techniques: a review. Pest Management Science, 62, 584-597. http://dx.doi.org/10.1002/ ps.1219

Costa, F. de S., Bayer, C., Albuquerque, J. A., \& Fontoura, S. M. V. (2004). Aumento de matéria orgânica num latossolo bruno em plantio direto. Ciência Rural, 34, 587-589. http://dx.doi.org/10.1590/S0103-84782004000200041

Empresa Brasileira de Pesquisa Agropecuária. Ministério da Agricultura, Pecuária e Abastecimento. (2006). Sistema Brasileiro de Classificação de Solos (2nd ed.). Rio de Janeiro, RJ: Embrapa CNPSO.

Fornasieri Filho, D., \& Fornasieri, J. L. (2006). Manual da cultura do arroz. Jaboticabal, SP: Funep.

Gasparim, L., Ricieri, R. P., Silva, S. de L., Dallacort, R., \& Gnoatto, E. (2005). Temperatura no perfil do solo utilizando duas densidades de cobertura e solo nu. Acta Scientiarum Agronomy, 27, 107-115. http://dx.doi.org/10.4025/actasciagron.v27i1.2127 
Geraldo, J., Rossiello, R. O. P., Araújo, A. P., \& Pimentel, C. (2000). Diferenças em crescimento e produção de grãos entre quatro cultivares de milheto perola. Pesquisa Agropecuária Brasileira, 35, 1367-1376. http://dx.doi.org/10.1590/S0100-204X2000000700011

Leite, C. R. F., Almeida, J. C. V., \& Prete, C. E. C. (1998). Aspectos fisiológicos, bioquímicos e agronômicos dos herbicidas inibidores da ALS (AHAS). Londrina, PR: Grafmark.

Machado, R. F., Barros, A. C. S. A., Zimmer, P. D., \& Amaral, A. dos S. (2006). Reflexos do mecanismo de ação de herbicidas na qualidade fisiológica de sementes e na atividade enzimática em plântulas de arroz. Revista Brasileira de Sementes, 28, 151-160. http://dx.doi.org/10.1590/S0101-31222006000300022

Oliveira, T. K., Carvalho, G. J., \& Moraes, R. N. S. (2002). Plantas e cobertura e seus efeitos sobre o feijoeiro em plantio direto. Pesquisa Agropecuária Brasileira, 1079-1087. http://dx.doi.org/10.1590/S0100-204X2002000800005

Pacheco, L. P., Barbosa, J. M., Leandro, W. M., Machado, P. L. O. de A., Assis, R. L. de, Madari, B. E., \& Petter, F. A. (2011). Produção e ciclagem de nutrientes por plantas de cobertura nas culturas de arroz de terras altas e de soja. Revista Brasileira de Ciência do Solo, 35, 1787-1799. http://dx.doi.org/10.1590/S0100-06832011000500033

Pacheco, L. P., Pires, F. R., Monteiro, F. P., Procópio, S. O., Assis, R. L., Cargnelutti, F., Carmo, M. L., \& Petter, F. A. (2009). Sobressemeadura da soja como técnica para supressão da emergência de plantas daninhas. Planta Daninha, 27, 455-463. http://dx.doi.org/10.1590/S0100-83582009000300005

Petter, F. A, Zuffo, A. M., \& Pacheco, L. P. (2011). Seletividade de herbicidas inibidores de ALS em diferentes estádios de desenvolvimento do arroz de terras altas. Pesquisa Agropecuária Tropical, 41, 408-414. http://dx.doi.org/10.5216/pat.v41i3.11584

Petter, F. A., Pacheco, L. P., Zuffo, A. M., Alcântara Neto, F., \& Ribeiro, W. R. M. (2012). Herbicidas inibidores da ALS aplicados em pós-emergência no arroz de terras altas. Planta Daninha, 30, 617-625. http://dx.doi.org/10.1590/S0100-83582012000300018

Pinheiro, B. S. (2006). Características morfológicas da planta relacionadas a produtividade. In A. B. Santos, L. F. Stone, \& N. R. A. Vieira (Eds.), A cultura do arroz no Brasil (2nd ed., pp. 209-256). Santo Antonio de Goiás, GO: Embrapa Arroz e Feijão.

Rajguru, S. N., Burgos, N. R., Shivrain, V. K., \& Stewart, J. McD (2005). Mutations in the red rice ALS gene associated with resistance to imazethapyr. Weed Science, 53, 567-577. http://dx.doi.org/10.1614/WS-04-111R1.1

Ray, T. B. Site of Action of Chlorsulfuron: Inhibition of Valine and Isoleucine Biosynthesis in Plants. (1984). Plant Physiology, 75, 827-831. http://dx.doi.org/10.1104/pp.75.3.827

Rodrigues, B. N., \& Almeida, F. S. (2005). Guia de Herbicidas (5st ed.). Londrina: Edição dos autores.

Sanchotene, D. M., Dornelles, S. B., Perini, F., Gonçalves, R. A., \& Estevo, A. P. (2009). Effect os ALS and ACCASE inhibitor herbicides over the morphology of watered rice crops. Revista FZVA, 16(1), 79-85. Retrieved from http://revistaseletronicas.pucrs.br/ojs/index.php/fzva/article/viewFile/3620/4167

Silva, A. C., Freitas, R. S., Ferreira, L. R., \& Fontes, P. C. R. (2009). Acúmulo de macro e micronutrientes por soja e Brachiaria brizantha emergida em diferentes épocas. Planta Daninha, 27, 49-56. http://dx.doi.org/10.1590/S0100-83582009000100008

Steinmetz, S., Silva, S. C., \& Santana, N. M. P. (2006). Clima. In: A. B. Santos, L. F. Stone, \& N. R. A. Vieira (ed.), A cultura do arroz no Brasil (2nd ed., pp. 117-160). Santo Antonio de Goiás, GO: Embrapa Arroz e Feijão.

Stone, L. F., \& Moreira, J. A. A. (2000). Efeitos de sistemas de preparo de solo no uso da água e na produtividade do feijoeiro. Pesquisa Agropecuária $\quad$ Brasileira, $\quad 35,841$. http://dx.doi.org/10.1590/S0100-204X2000000400022

Stone, L. F., \& Pereira, A. L. (1994). Sucessão arroz-feijão irrigados por aspersão: efeitos do espaçamento entre linhas, adubação e cultivar no crescimento, desenvolvimento radicular e consumo de água do arroz. Pesquisa $\begin{array}{lllll}\text { Agropecuária } \quad \text { Brasileira, } & \text { 29, } & \text { Retrieved } & \text { from }\end{array}$ http://webnotes.sct.embrapa.br/pdf/pab1994/outubro/pab13_out_94.pdf

Taiz, L., \& Zeiger, E. (2009). Fiosiologia Vegetal. (4nd ed.). Porto Alegre, RS: Artmed. 
Tranel, P. J., \& Wright, T. R. (2002). Resistence of weeds to ALS-inhibiting herbicides: what have we learned? Weed Science, 50, 700-712. http://dx.doi.org/10.1614/0043-1745(2002)050[0700:RROWTA]2.0.CO;2

Vidal, R. (2002). Ação dos herbicidas (1nd ed.). Porto Alegre: Edição do autor.

\section{Copyrights}

Copyright for this article is retained by the author(s), with first publication rights granted to the journal.

This is an open-access article distributed under the terms and conditions of the Creative Commons Attribution license (http://creativecommons.org/licenses/by/3.0/). 